\title{
Prevalence and risk factors of hepatitis B in Spanish prostitutes
}

\author{
By L. REQUENA CABALLERO,* C. REQUENA CABALLERO, \\ I. REQUENA CABALLERO, M. SÁNCHEZ LÓPEZ \\ Department of Dermatology, Military Hospital 'Gómez-Ulla', Madrid \\ F. VÁZQUEZ LÓPEZ \\ Department of Dermatology, Clinic Hospital 'San Carlos', Madrid \\ J. ROMERO GUERRERO AND M. CASADO JIMÉNEZ \\ 'Martinez-Anido' STD Clinic, Madrid
}

(Accepted 20 February 1987)

\begin{abstract}
SUMMARY
Eighty prostitutes were tested by solid-phase radioimmunoassay for serum markers of hepatitis B virus (HBV). Of $8(10 \%)$ with hepatitis $B$ surface antigen (HBsAg), 6 (75\%) also had hepatitis Be antigen (HBeAg). Antibodies to $\mathrm{HBsAg}$ (anti-HBs) and to hepatitis B core antigen (anti-HBc) were found in $52(65 \%)$. Antibodies to $\mathrm{HBeAg}$ (anti-HBe) were positive in $32(40 \%)$. Anti-HBc alone was found in $5(6 \%)$ and anti-HBs alone in $2(2 \%)$. Sixty-seven $(84 \%)$ were positive for at least one HBV marker and $13(16 \%)$ were still susceptible to infection. Hepatitis B markers were more prevalent in prostitutes than in the normal Spanish population. Age, a history of sexually transmitted diseases (STD), drug abuse and promiscuity are factors which were highly related to hepatitis B markers. We concluded that screening prostitutes for the presence of markers and vaccinating those who are negative would be worth while.
\end{abstract}

\section{INTRODUCTION}

High levels of efficacy and safety of hepatitis B vaccine have been demonstrated in well-designed controlled clinical trials among high-risk populations (Szmuness et al. 1980, 1981). Nevertheless, the high cost of this vaccine forces us to choose the candidates for this vaccination very carefully. Logically, the vaccination should only be given to those who are susceptible. Therefore, in high risk groups, prior screening for serum markers followed by vaccination only of those who are negative is the lowest-cost strategy because it allows important savings in the number of doses of vaccine (Mulley, Silverstein \& Dienstag, 1982).

Several epidemiological studies have demonstrated high rates in the prevalence of serum markers of HBV among heterosexual patients attending STD clinics (Jeffries et al. 1973; Fulford et al. 1973), prostitutes (Papaevangelou et al. 1974;

* Correspondence should be addressed to Dr L. Requena Caballero, C/ Leopoldo Alas Clarin 4-6F, 28035 Madrid, Spain. 
Frosner, Buchholtz \& Gerth, 1975; Hoop et al. 1984) and male homosexuals (Szmuness et al. 1975; Schreeder et al. 1982).

To calculate prevalence of $\mathrm{HBV}$ infection in prostitutes and to formulate indications for the use of hepatitis B vaccine, we have tested for serum markers of HBV in prostitutes attending an STD clinic in Madrid. In addition we included, within an epidemiological questionnaire which the prostitutes answered voluntarily, several questions on sexual behaviour and other risk factors for HBV infection. We also compared our results with data from previously published studies in prostitutes and with the prevalence reported in the normal Spanish population (Vargas et al. 1982).

\section{MATERIALS AND METHODS}

To test for the presence of $\mathrm{HBsAg}$, anti-HBs, HBeAg, anti-HBe and anti-HBc, we took blood sample from 80 prostitutes attending the Martínez-Anido Clinic, an STD clinic in Madrid.

In this study we have included only the serum samples from prostitutes who answered voluntarily all the following questions: age, history of STD, number of sexual partners in the last month, number of sexual partners in the last year, history of hepatitis or previous liver disease and parenteral exposure (blood transfusion and intravenous drug addiction). They were assured that all personal information would be kept confidential and we noted details of STD or the reason for consultation.

We collected $10 \mathrm{ml}$ of blood from each prostitute and the serum samples were stored at $-70^{\circ} \mathrm{C}$ prior to testing for serum markers of $\mathrm{HBV}$ in batches.

We used solid-phase radioimmunoassays (RIA) as commercial kits made by Abbott Laboratories (AUSRIA-II, AUSAB, Abbott-HBe and CORAB). The sera which were positive for HBsAg were sent to Dr A. M. Couroucé of the Blood Transfusion Centre of Paris, who had kindly agreed to subtype the surface antigen by an electroimmunodiffusion technique.

In accordance with currently accepted criteria (Deinhardt, 1982), we have assumed that prostitutes with positive results for anti-HBc and anti-HBs had overcome the infection and had developed immunity. Serum samples positive only for anti-HBs could be either immune patients or those with cross-reacting antibody (false positive) (Werner et al. 1985). A positive test for anti-HBc only can indicate either the 'window period' or long-past infection. Therefore those positive 'only for anti-HBs' and 'only for anti-HBc' are two serological patterns which are difficult to interpret especially when their level is unknown. We have listed these two patterns separately and we draw no conclusions about active or past infection based on these results. Nevertheless, because we have used a very specific and sensitive method of testing (RIA) and these serum samples were positive in two different assays, we have considered these results to be genuinely positive and we have included them in the 'any positive marker' group. We considered that any serum marker positive for HBV meant previous contact with the virus and was included as an epidemiological marker. We also assumed that all prostitutes with negative screening tests for serum markers would be susceptible to infection and, therefore, candidates for vaccination. 
Table 1. Prevalence of serum markers of $H B V$ in prostitutes

Positive for HBsAg

$\begin{array}{rr}n & \% \\ 8 & 10 \\ 32 & 40 \\ 52 & 65 \\ 5 & 6 \\ 2 & 2 \\ 67 & 84\end{array}$

Positive for anti-HBs, anti-HBe and anti-HBc

Positive for anti-HBs and anti-HBc

Positive for anti-HBc alone

Positive for anti-HBs alone

Any positive marker

$67 \quad 84$

Table 2. Serologic patterns in prostitutes positive for HBsAg

\begin{tabular}{|c|c|c|c|c|c|c|c|c|}
\hline Case & Age & STD & HBsAg & $\begin{array}{l}\text { HBsAg } \\
\text { subtypes }\end{array}$ & Anti-HBs & HBeAg & Anti-HBe & Anti-HB \\
\hline 1 & 25 & Multiple STD & + & Not typed & - & + & - & + \\
\hline 2 & 26 & Multiple STD & + & ayw2 & - & - & - & - \\
\hline 3 & 31 & $\begin{array}{l}\text { Secondary } \\
\text { syphilis }\end{array}$ & + & Not typed & - & + & - & 一 \\
\hline 4 & 36 & NGU & + & Not typed & - & - & - & + \\
\hline 5 & 29 & $\begin{array}{l}\text { Primary } \\
\text { syphilis }\end{array}$ & + & $a d w 2$ & - & + & - & - \\
\hline 6 & 28 & $\begin{array}{l}\text { Primary } \\
\text { syphilis }\end{array}$ & + & $a d w 2$ & - & + & - & - \\
\hline 7 & 39 & NGU & + & $a d w 2$ & - & + & - & + \\
\hline 8 & 26 & Multiple STD & + & Not typed & - & + & - & + \\
\hline
\end{tabular}

Table 3. Epidemiological characteristics of the prostitutes in the study

Reasons for consultation

\section{Syphilis \\ SMPS* \\ Trichomoniasis \\ Candidiasis \\ NGUt \\ Gonorrhoea \\ Multiple sTI)}

History of STD

Yes

22

No

58

Drug abuse

Yes

No

Blood

transfusion

Yes

No

Previous

hepatitis

Yes

No

$\begin{array}{lcc}(\%) & \text { Age } & n \\ (10) & 17-45 \text { years } & 80 \\ (41) & 17-20 \text { years } & 10 \\ (11) & 21-25 \text { years } & 19 \\ (6) & 26-30 \text { years } & 19 \\ (9) & 31-35 \text { years } & 20 \\ (5) & \text { More than } & 12 \\ (17) & 35 \text { years } & \end{array}$

Number of

(\%) sexual partners $n$

(100) (a) In the last month

(13) 1-5 9

(23) $\quad 6-30 \quad 57$

More than $30 \quad 14$

(b) In the last year

1-20

$21-50$

$51-100$

101-300

23

More than 300

$\begin{aligned} 22 & (28) \\ 58 & (72) \\ 7 & (9) \\ 73 & (91) \\ & \\ 0 & (0) \\ 80 & (100) \\ & \\ 8 & (10) \\ 72 & (90)\end{aligned}$

* SMPS: Serological monitoring of previous syphilis.

$\dagger$ NGU: non-gonococcal urethritis. 


\section{RESULTS}

Table 1 shows the prevalence of HBV markers in prostitutes. Eight $(10 \%)$ prostitutes were positive for $\mathrm{HBsAg}, 52(65 \%)$ were immune against $\mathrm{HBV}$ and $13(16 \%)$ were susceptible. The combined prevalence, a measure of past and current hepatitis B by any positive marker, was $67(84 \%)$.

Table 2 shows further details of the 8 prostitutes positive for HBsAg. Of these $6(75 \%)$ were also positive for $\mathrm{HBeAg}$ and $4(50 \%)$ were positive for anti-HBc. Anti-HBe antibodies were not detected in any of their sera. Patient no. 2 was positive only for $\mathrm{HBsAg}$. The $\mathrm{HBsAg}$ subtype could be determined only in 4 cases (one 'ayw2' and three ' $a d w 2$ '). The other 4 cases had very low levels of $\mathrm{HBsAg}$ which could not be subtyped.

Table 3 summarizes the epidemiological details of the subjects. Thirty-three prostitutes $(41 \%)$ attended the clinic for serological monitoring of previous syphilis and $47(59 \%)$ had different types of STD at the time the specimens of blood were collected. Their ages ranged between 17 and 45 years. Twenty-two prostitutes $(28 \%)$ had a history of past STD, $7(9 \%)$ of drug abuse, $8(10 \%)$ had had hepatitis but none of the participants in this study had had a blood transfusion.

Tables 4-8 compare the prevalence of HBV markers with type of STD, with age, with a past history of STD, with drug abuse, and with promiscuity, respectively.

\section{DISCUSSION}

Comparing our results with the normal population in Spain (Vargas et al. 1982), we found a greater prevalence of all serum markers of $\mathrm{HBV}$ among prostitutes: HBsAg: $10 \%$ vs $1 \cdot 8 \%$; past infection: $65 \%$ vs $15 \%$ and any positive marker : $84 \%$ vs $24.4 \%$. Despite the average age of these two groups being not strictly comparable, and the fact that our laboratory tests were more sensitive (RIA vs passive haemagglutination), it is reasonable to conclude that the prostitutes should be considered to be a high-risk group for acquiring infection with HBV.

An important finding among those positive for $\mathrm{HBsAg}$ was the high rate of $\mathrm{HBeAg}$ positivity. These data indicate that prostitutes positive for $\mathrm{HBsAg}$ are highly infectious (Shikata, Karasawa \& Abe, 1977). Three prostitutes positive for both $\mathrm{HBsAg}$ and $\mathrm{HBeAg}$ but with no anti-HBc and one prostitute with $\mathrm{HBsAg}$ as the only positive marker were thought to be late in the incubation period or in the very early stages of an acute infection. Follow-up of these patients confirmed this opinion because other serum markers for $\mathrm{HBV}$ appeared later.

When the HBV markers were compared with type of STD, the patients with syphilis, non-gonococcal urethritis (NGU) and multiple STD showed a higher frequency of HBsAg positives than the other types of STD. Syphilis can be thought of as a systemic disease with early liver damage (Feher et al. 1975) and with some suppression of cellular immunity (Baker-Zander, Sell \& Lukerhart, 1982). Although both these factors can increase the risk for HBV infection in patients with syphilis, we do not have an explanation for the high prevalence in patients with NGU and with multiple STDs. On the other hand, whereas some have found a higher prevalence among STD patients with a history of syphilis 
Table 4. Prevalence of $H B V$ markers by type of STD

\begin{tabular}{|c|c|c|c|c|c|c|}
\hline STD & $n$ & $\begin{array}{c}\text { HBsAg- } \\
\text { Positive } \\
n(\%)\end{array}$ & $\begin{array}{c}\left.\begin{array}{c}\text { Past infection } \\
n(\%)\end{array}\right) \\
\overbrace{}^{(\%)}\end{array}$ & $\begin{array}{l}\text { Isolated anti- } \\
\text { HBc-positive }\end{array}$ & $\begin{array}{l}\text { Isolated anti- } \\
\text { HBs-positive }\end{array}$ & $\begin{array}{c}\text { Any positive } \\
\text { marker } \\
n(\%)\end{array}$ \\
\hline Syphilis & 8 & $3(37)$ & $4(50)$ & 0 & 0 & $7(87)$ \\
\hline SMPS* & 33 & $0(0)$ & $25(75)$ & 4 & 1 & $30(90)$ \\
\hline Trichomoniasis & 9 & $0(0)$ & $6(66)$ & 1 & 1 & $8(88)$ \\
\hline Candidiasis & 5 & $0(0)$ & $3(60)$ & 0 & 0 & $3(60)$ \\
\hline NGU† & 7 & $2(28)$ & $3(42)$ & 0 & 0 & $5(71)$ \\
\hline Gonorrhoea & 4 & $0(0)$ & $2(50)$ & 0 & 0 & $2(50)$ \\
\hline Multiple STD & 14 & $3(21)$ & $9(64)$ & 0 & 0 & $12(85)$ \\
\hline Total & 80 & $8(10)$ & $52(65)$ & $5(6)$ & $2(2)$ & $67(84)$ \\
\hline
\end{tabular}

Table 5. Prevalence of $H B V$ markers by age

\begin{tabular}{|c|c|c|c|c|c|c|}
\hline Range of age & $n$ & $\begin{array}{c}\text { HBsAg- } \\
\text { Positive } \\
n(\%)\end{array}$ & $\begin{array}{c}\text { Past infection } \\
n(\%)\end{array}$ & $\begin{array}{l}\text { Isolated anti- } \\
\text { HBc-positive }\end{array}$ & $\begin{array}{l}\text { Isolated anti- } \\
\text { HBs-positive }\end{array}$ & $\begin{array}{c}\text { Any positive } \\
\text { marker } \\
n(\%)\end{array}$ \\
\hline 17-20 years & 10 & $3(30)$ & $4(40)$ & 0 & 0 & $7(70)$ \\
\hline $21-25$ years & 19 & $3(15)$ & $10(50)$ & 1 & 0 & $14(73)$ \\
\hline $26-30$ years & 19 & $2(10)$ & $11(57)$ & 2 & 1 & $16(84)$ \\
\hline $31-35$ years & 20 & $0(0)$ & $17(85)$ & 1 & 1 & $19(85)$ \\
\hline More than 35 years & 12 & $0(0)$ & $10(83)$ & 1 & 0 & $11(91)$ \\
\hline Total & 80 & $8(10)$ & $52(65)$ & $5(6)$ & $2(2)$ & $67(84)$ \\
\hline
\end{tabular}

Table 6. Prevalence of HBV markers by STD history

\begin{tabular}{|c|c|c|c|c|c|c|}
\hline STD history & $n$ & $\begin{array}{c}\text { HBsAg- } \\
\text { Positive } \\
n(\%)\end{array}$ & $\begin{array}{c}\begin{array}{c}\text { Past infection } \\
n(\%)\end{array} \\
\end{array}$ & $\begin{array}{l}\text { Isolated anti- } \\
\text { HBc-positive }\end{array}$ & $\begin{array}{l}\text { Isolated anti- } \\
\text { HBs-positive }\end{array}$ & $\begin{array}{c}\text { Any positive } \\
\text { marker } \\
n(\%)\end{array}$ \\
\hline Yes & 58 & $7(12)$ & $40(60)$ & 5 & 2 & $54(93)$ \\
\hline No & 22 & $1(4)$ & $12(54)$ & 0 & 0 & $13(59)$ \\
\hline Total & 80 & $8(10)$ & $52(65)$ & $5(6)$ & $2(2)$ & $67(84)$ \\
\hline
\end{tabular}

(Kruger et al. 1982; Lacey, Meaden \& Clarke, 1983; Coester et al. 1984), others have reported a higher prevalence only in patients with a history of STD in general (Frosner et al. 1975; Hoop et al. 1984 ; Szmuness et al. 1975; Kacaki et al. 1975 ; Lim et al. 1977; Schneider et al. 1977). This apparent disparity is possibly due to some of these studies including only serological tests for syphilis in the STD screening, and no other STD was investigated. We believe that the association between hepatitis B and one type or another of STD is casual.

As was to be expected, the proportion of cases with any marker for HBV increased with age due to their persistence after initial infection, confirmed by the majority of serum samples positive for HBsAg being found in the younger prostitutes. If the age of starting prostitution is similar in all prostitutes, this trend towards a decrease in the prevalence of $\mathrm{HBsAg}$ positivity and an increase in 
Table 7. Prevalence of $H B V$ markers by history of drug abuse

\begin{tabular}{|c|c|c|c|c|c|c|}
\hline $\begin{array}{l}\text { Drug abuse } \\
\text { history }\end{array}$ & $n$ & $\begin{array}{c}\text { HBsAg- } \\
\text { Positive } \\
n(\%)\end{array}$ & $\begin{array}{c}\text { Past infection } \\
n(\%)\end{array}$ & $\begin{array}{l}\text { Isolated anti- } \\
\text { HBc-positive }\end{array}$ & $\begin{array}{l}\text { Isolated anti- } \\
\text { HBs-positive }\end{array}$ & $\begin{array}{c}\text { Any positive } \\
\text { marker } \\
n(\%)\end{array}$ \\
\hline $\begin{array}{l}\text { Yes } \\
\text { No } \\
\text { Total }\end{array}$ & $\begin{array}{r}7 \\
73 \\
80\end{array}$ & $\begin{array}{l}\overbrace{2(28)} \\
6(8) \\
8(10)\end{array}$ & $\begin{array}{r}4(57) \\
48(65) \\
52(65)\end{array}$ & $\begin{array}{c}1 \\
4 \\
5(6)\end{array}$ & $\begin{array}{c}0 \\
2 \\
2(2)\end{array}$ & $\begin{aligned} & 7(100) \\
& 60(82) \\
& 67(84)\end{aligned}$ \\
\hline
\end{tabular}

Table 8. Prevalence of $H B V$ markers by promiscuity

\begin{tabular}{|c|c|c|c|c|c|c|}
\hline $\begin{array}{l}\text { Number of } \\
\text { sexual partners }\end{array}$ & $n$ & $\begin{array}{c}\text { HBsAg- } \\
\text { Positive } \\
n(\%)\end{array}$ & $\begin{array}{c}\text { Past infection } \\
n(\%)\end{array}$ & $\begin{array}{l}\text { Isolated anti- } \\
\text { HBc-positive }\end{array}$ & $\begin{array}{l}\text { Isolated anti- } \\
\text { HBs-positive }\end{array}$ & $\begin{array}{c}\text { Any positive } \\
\text { marker } \\
n(\%)\end{array}$ \\
\hline \multicolumn{7}{|c|}{ In the last month } \\
\hline $1-5$ & 9 & $0(0)$ & $5(55)$ & 1 & () & $6(66)$ \\
\hline 6-30 & 57 & $5(9)$ & $37(64)$ & 4 & 2 & $48(84)$ \\
\hline More than 30 & 14 & $3(21)$ & $10(71)$ & 0 & 0 & $13(92)$ \\
\hline Total & 80 & $8(10)$ & $52(65)$ & $5(6)$ & $2(2)$ & $67(84)$ \\
\hline \multicolumn{7}{|l|}{ In the last year } \\
\hline $1-20$ & 5 & $0(0)$ & $3(60)$ & 0 & 0 & $3(60)$ \\
\hline $21-50$ & 9 & $0(0)$ & $6(66)$ & 1 & 0 & $7(77)$ \\
\hline $51-100$ & 23 & $2(8)$ & $14(60)$ & 2 & 1 & $19(82)$ \\
\hline $101-300$ & 25 & $3(12)$ & $16(64)$ & 2 & 1 & $22(88)$ \\
\hline More than 300 & 18 & $3(16)$ & $13(72)$ & 0 & 0 & $16(88)$ \\
\hline Total & 80 & $8(10)$ & $52(65)$ & $5(6)$ & $2(2)$ & $67(84)$ \\
\hline
\end{tabular}

the markers of past infection with age is consistent with sexual transmission of HBV.

Other risk factors seem to be a history of STD and of intravenous drug addiction. The higher frequency of HBV markers in prostitutes with a history of STD is also consistent with promiscuity, because the risk of STD is proportional to promiscuity. Drug abuse is a well-known risk factor for parenteral acquisition of hepatitis B. It has been suggested (Dietzman et al. 1977) that the ay subtype of $\mathrm{HBsAg}$ is preponderant in serum samples from patients with acute hepatitis B who admitted self-injection of drugs, whereas the $a d$ subtype was preponderant in patients without a history of parenteral exposure. In our study, three cases were positive for $a d w 2$ and one for ayw2. Unfortunately the other four positive HBsAg sera could not be subtyped and no conclusions could be drawn.

There was a strong relationship between promiscuity and markers for HBV, either HBsAg or others indicating past infection. There is also a relationship between HBV infection and promiscuity both in the last month and in the last year. Therefore if promiscuity carries a higher risk of contracting STD, hepatitis $B$ is no exception. Nevertheless $12 \%$ of the prostitutes in the group of higher promiscuity had no HBV marker. These susceptible prostitutes, except in promiscuity, were epidemiologically similar to the other prostitutes.

A comparison with other similar studies (Table 9) is necessary considering that the patterns of HBV infection vary in different countries and that laboratory techniques vary in sensitivity.

As in other epidemiological studies, many of these $\mathrm{HBV}$ infections are 
Table 9. Epidemiological studies by $\mathrm{HBV}$ markers in prostitutes

Percentage with

\begin{tabular}{|c|c|c|c|c|c|c|}
\hline Reference & Country & $\mathrm{HBsAg}$ & Anti-HBs & $\mathrm{HBeAg}$ & Anti-HBe & Anti-HBc \\
\hline $\begin{array}{l}\text { Frosner } \\
\text { et al. (1975) }\end{array}$ & $\begin{array}{l}\text { German } \\
\text { Federal } \\
\text { Republic }\end{array}$ & $2.3(\mathrm{PHA})$ & *31 (PHA) & - & - & - \\
\hline $\begin{array}{l}\text { Papaevangelou } \\
\text { et al. (1974) }\end{array}$ & Greece & 4.4 (CIP) & 56.7 (PHA) & - & - & - \\
\hline $\begin{array}{l}\text { Kaklamani } \\
\text { et al. }(1980)\end{array}$ & Greece & 11 (RIA) & 60 (RIA) & - & - & 60 (RIA) \\
\hline $\begin{array}{l}\text { Adam } \\
\text { et al. (1979) }\end{array}$ & Colombia & 5 (RIA) & 20 (PHA) & - & - & - \\
\hline $\begin{array}{l}\text { (Goh } \\
\text { et al. (1985) }\end{array}$ & Singapore & 6 (RIA) & 64 (RIA) & $27(\mathrm{RIA}) \dagger$ & - & 63 (RIA) \\
\hline $\begin{array}{l}\text { Hoop } \\
\text { et al. (1984) }\end{array}$ & Netherlands & 2.3 (RIA) & 23 (RIA) & - & - & - \\
\hline Present study & Spain & 10 (RIA) & 65 (RIA) & 75 (RIA) $\dagger$ & 40 (RIA) & 71 (RIA) \\
\hline
\end{tabular}

* Laboratory technique used: (PHA), passive haemagglutination; (CIP), counterimmunoelectrophoresis; (RIA), radioimmunoassay.

† Only in serum samples positive for HBsAg.

subclinical, with only $10 \%$ of the prostitutes giving a history of hepatitis, and this increases the risk of spread of infection. Therefore, it is likely that prostitutes play a role in the spread of hepatitis B in urban populations, and we consider that a considerable economic saving could be made by offering vaccination against hepatitis B to prostitutes. This would decrease expenditure on treatment in the acute stage of infection and on the long-term sequelae (chronic carriers, chronic persistent and active hepatitis, cirrhosis and hepatocarcinoma). It would also be a very good prophylactic measure in the prevention of sexual transmission of hepatitis B.

We are grateful to Dr A. M. Couroucé, of the Blood Transfusion Centre of Paris, for subtyping of HBsAg.

\section{REFERENCES}

Adam, E., Hollinger, F. B., Melnick, J. L., Dueñas, A. \& Rawls, W. E. (1974). Type B hepatitis antigen and antibody among prostitutes and nuns: a study of possible venereal transmission. Journal of Infectious Diseases 129, 317-321.

Baker-Zander, S. A., Sell, S. \& Lukerhart, S. A. (1982). Serum regulation of in vitro lymphocyte responses in early experimental syphilis. Infection and Immunity 37, 568-578.

Coester, C. H., Avonts, D., Colaert, J., Desmyter, J. \& Piot, P. (1984). Syphilis, hepatitis A, hepatitis B and cytomegalovirus infection in homosexual men in Antwerp. British Journal of Venereal Diseases 60, 48-51.

DEINHARDT, F. (1982). Serum markers of hepatitis viruses in natural disease and after vaccination. In Progress in Liver Diseases, vol. viII (ed. H. Popper and F. Schaffner), pp. 451-457. New York: Grune and Stratton.

Dietzman, D. E., Harnisch, J. P., Ray, G., Alexander, E. R. \& Holmes, K. K. (1977). Hepaitis B surface antigen (HBsAg) and antibody to HBsAg. Prevalence in homosexual and heterosexual men. Journal of the American Medical Association 238, 2625-2626.

Feher, J., Somogyi, T., Timmer, M. \& Jozsa, L. (1975). Early syphilitic hepatitis. Lancet ii, 896-899. 
Frosner, G. G., Buchroltz, H. M. \& Gerth, H. J. (1975). Prevalence of hepatitis B antibody in prostitutes. American Journal of Epidemiology 102, 241-250.

Fulford, K. W. H., Dane, D. S., Catterall, R. D., Woof, R. \& Denning, J. V. (1973). Australia antigen and antibody among patients attending a clinic for sexually transmitted diseases. Lancet i, 1470-1473.

Goh, G. L., Kamarudin, A., Chan, S. H. \& RaJan, V. S. (1985). Hepatitis B virus markers in prostitutes in Singapore. Genitourinary Medicine 61, 127-129.

Hoop, D., Anker, W. J. J., StriJk, R. V., Masurel, N. \& Stolz, E. (1984). Hepatitis B antigen and antibody in the blood of prostitutes visiting an outpatient venereology department in Rotterdam. British Journal of Venereal Diseases 60, 319-322.

Jeffries, D. J., James, W. H., Jefferies, F. J. G., Macleod, K. G. \& Willcox, R. R. (1973). Australia (hepatitis-associated) antigen in patients attending a venereal disease clinic. British Medical Journal 24, 455-456.

Kacaki, J., Schuurs, A. H. W., Wolters, G. \& Lalosevic, J. (1975). Hepatitis B antigen in venereal diseases. Lancet ii, 363-364.

Kaklamani, E., Kyriakidou, A., Trichopoulos, D., Papoutsakis, G., Koumandaki, I. \& Karalis, D. (1980). Hepatitis B serology in Greek prostitutes: significance of the different serum markers. Journal of Hygiene 84, 257-261.

Kruger, P., Pedersen, N. S., Mathiesen, L. \& Nielsen, J. O. (1982). Increased risk of infection with hepatitis $A$ and $B$ viruses in men with history of syphilis. Relation to sexual contacts. Journal of Infectious Diseases 145, 23-26.

Lacey, C. J. N., Meaden, J. D. \& Clarke, S. K. R. (1983). Hepatitis B virus infections in homosexual men. British Journal of Venereal Diseases 59, 277-278.

Lim, K. S., Wongt, V. T., Fulford, K. W. M., Catterall, R. D., Briggs, M. \& Dane, D. S. (1977). Role of sexual and non sexual practices in the transmission of hepatitis B. British Journal of Venereal Diseases 53, 190-192.

Mulley, A. G., Silverstein, M. D. \& Dienstag, J. L. (1982). Indication for use of hepatitis B vaccine based on cost-effectiveness analysis. New England Journal of Medicine 307, 644652.

Papaevangelou, G., Trichopoulos, D., Kremastinou, T. \& Papoutsakis, G. (1974). Prevalence of hepatitis B antigen and antibody in prostitutes. British Medical Journal ii, 256-258.

Schneider, J., King, L., Macnab, G. M. \& Kew, M. C. (1977). Hepatitis B surface antigen and antibody in black and white patients with venereal diseases. British Journal of Venereal Diseases 53, 372-374.

Schreeder, M. T., Thompson, S. E., Hadler, S. C., Berquist, K. R., Zaidi, A., Maynard, J. E., Ostrow, D., Judson, F. N., Braff, E. H., Ny-Lund, T., Moore, J. N., Gardner, P., Doto, I. L. \& ReYnolds, G. (1982). Hepatitis B in homosexual men. Prevalence of infection and factors related to transmission. Journal of Infectious Diseases 146, 7-15.

Shikata, T., Karasawa, T. \& Abe, K. (1977). Hepatitis Be antigen and infectivity of hepatitis B virus. Journal of Infectious Diseases 136, 571-576.

Szmuness, W., Much, M. I., Prince, A. M., Hoffnagle, J. H., Cherubin, C. E., Harley, E. J. \& BLock, G. H. (1975). On the role of sexual behaviour in the spread of hepatitis B infection. Annals of Internal Medicine 83, 489-495.

Szmuness, W., Stevens, C. E., Harley, E. J., Zang, E. A., Oleszko, W. R., William, D. C., Sadovsky, R., Morrison, J. M. \& Kellner, A. (1980). Hepatitis B vaccine. Demonstration of efficacy in a controlled clinical trial in a high-risk population in the United States. New England Journal of Medicine 303, 833-841.

Szmuness, W., Stevens, C. E., Zang, E. A., Harley, E. J. \& Kellner, A. (1981). A controlled clinical trial of efficacy of the hepatitis B vaccine (Heptavax B) : a final report. Hepatology 1 , 377-385.

Varqas, V., Pedreira, J. D., Esteban, R., Hernandez, J. M., Piqueras, J. \& Guardia, J. (1982). Marcadores serológicos de la hepatitis B en población sana. Medicina Clinica 78, 265-267.

Werner, W. G., Dienstag, J. L., Kuter, B. J. Polk, B. F., Snydman, D. R., Craven, D. E., Crumpacker, C. S., Plate, R. \& Grady, G. F. (1985). Isolated antibody to hepatitis B surface antigen and response to hepatitis B vaccination. Annals of Internal Medicine 103, 201-205. 